\title{
Peningkatan Minat Belajar Siswa Melalui Media Pembelajaran Berbasis Teknologi Informasi
}

\author{
Aisyah Nursyam ${ }^{1}$ * \\ ${ }^{1}$ STKIP Muhammadiyah Bone. Biru, Tanete Riattang, Kabupaten Bone, Sulawesi Selatan, Indonesia. \\ * Korespondensi Penulis. E-mail: ichanursyam@gmail.com
}

\begin{abstract}
Abstrak
Penelitian ini bertujuan untuk melihat peningkatan hasil belajar melalui media pembelajaran berbasis teknologi informasi pada siswa kelas X IPA 3 SMA Negeri 9 Bone. Penelitian ini merupakan penelitian tindakan kelas (Class Room Assessment). Instrumen yang digunakan untuk mengunpulkan data adalah lembar observasi keterlaksanaan pembelajaran (aktifitas guru), lembar observasi aktifitas siswa, angket respon siswa, dan tes hasil belajar pada tiap siklus. Data yang diperoleh dianalisis menggunakan analisis deskriptif kuantitatif dan analisis kualitatif. Analisis deskriptif kuantitatif digunakan untuk mengetahui hasil belajar siswa, sementara analisis kualitatif digunakan untuk mengetahui hasil observasi aktifitas siswa. Hasil penelitian menunjukkan bahwa pembelajaran dengan menggunakan media berbasis teknologi informasi dapat meningkatkan minat belajar siswa kelas $\mathrm{X}$ IPA.3 SMA Negeri 9 Bone. Hal ini dapat dilihat dari rata-rata hasil belajar siswa kelas X IPA.3SMA Negeri 9 Watampone pada siklus I sebesar $67,34 \%$ dan pada siklus II rata-rata hasil belajar siswa meningkat menjadi $83,19 \%$. Aktifitas siswa dalam proses pembelajaran juga mengalami peningkatan, meskipun berdasarkan lembar aktivitas siswa pada siklus I masih dirasakan beberapa kendala namun pada siklus II menunjukan adanya peningkatan secara signifikan. Angket respon siswa pada siklus I ada 15 item dengan presentase rata-rata secara keseluruhan yaitu 77,36\% dan pada siklus II 81,53\%.
\end{abstract}

Kata Kunci: Minat Belajar, Media Pembelajaran, Tekhnologi Informasi

\section{Increased Interest in Student Learning Through Information Technology- Based Learning Media}

\begin{abstract}
This study aims to see an increase in learning outcomes through information technology-based learning media in class X IPA 3 students at 9 Bone State High School. This research is a Class Room Assessment. The instruments used to collect data are the implementation observation observation sheets (teacher activities), student activity observation sheets, student response questionnaires, and learning outcomes tests in each cycle. The data obtained were analyzed using quantitative descriptive analysis and qualitative analysis. Quantitative descriptive analysis is used to determine student learning outcomes, while qualitative analysis is used to determine the results of observations of student activities. The results of the study indicate that learning using information technology-based media can increase the learning interest of class X students of Science 3 in Bone 9 High School. This can be seen from the average learning outcomes of class $X$ students of IPA 3SMA 9 Watampone in the first cycle of 67.34\% and in the second cycle the average student learning outcomes increased to $83.19 \%$. Student activities in the learning process also experienced an increase, although based on the student activity sheet in the first cycle there were still some obstacles but in the second cycle there was a significant increase. Questionnaire responses of students in the first cycle there were 15 items with an overall percentage of $77.36 \%$ and in the second cycle $81.53 \%$.
\end{abstract}

Keywords: one or more word(s) or phrase(s), that it's important, spesific, or representative for the article 


\section{PENDAHULUAN}

Gagasan bahwa teknologi dapat mengubah hidup kita secara signifikan menjadi wacana publik yang terus menerus diperbincangkan, baik di dalam maupun di luar akademi. Klaim bahwa teknologi dapat memberikan perubahan lebih cepat dibanding hal lainnya dalam sejarah manusia seringkali membawa rasa urgensi, mendesak kita untuk mengikuti perubahan dan meningkatkan kekhawatiran bahwa beberapa masyarakat kita tertinggal. Kartun dengan lucu menggambarkan kesenjangan antara orang-orang muda yang telah tumbuh dengan teknologi dan generasi yang lebih tua yang tampaknya menjadi misteri atau ancaman. Visi utopis tentang dunia baru yang berani dibuka oleh perubahan teknologi yang mempromosikan kesetaraan yang lebih besar dan keaktifan dalam partisipasi. Apa yang mendasari semua konsepsi kehidupan modern ini adalah gagasan bahwa kemajuan teknologi menciptakan perubahan masyarakat yang membutuhkan pendekatan dan praktik baru. Pendidikan, diklaim, adalah arena kunci untuk perubahan radikal. ${ }^{1}$

Perubahan radikal dalam pendidikan diperlukan karena lembaga tradisional tidak memenuhi kebutuhan generasi baru pelajar 'yang mengerti teknologi'. Generasi muda ini dikatakan berbeda dari semua generasi yang telah ada sebelumnya karena mereka berpikir, berperilaku, dan belajar secara berbeda sebagai hasil dari paparan yang terus menerus dan luas terhadap teknologi modern. Berbagai label telah diterapkan pada generasi muda ini, tetapi ada dua yang paling umum adalah "digital natives" dan "the Net Generation". Fitur utama dari konsepsi generasi muda sebagai "digital natives"" adalah tampaknya kesenjangan yang tidak dapat diatasi antara mereka dan generasi yang lebih tua yang kurang melek teknologi. Argumen yang dibuat adalah bahwa satu-satunya masalah terbesar yang dihadapi pendidikan saat ini adalah instruktur teknologi yang ketinggalan zaman (yang dari zaman pra-digital), berjuang untuk mengajar populasi yang berbicara bahasa yang sama sekali baru. ${ }^{3}$

Dalam dunia pendidikan, perkembangan teknologi informasi telah membawa perubahan yang sangat besar bagi kemajuan dunia pendidikan. Seiring dengan perkembangan tersebut metode pembelajaran juga banyak mengalami perkembangan, baik metode pembelajaran secara personal, media pembelajaran ataupun proses pembelajaran. Bentuk dari perkembangan teknologi informasi yang diterapkan di dunia pendidikan merupakan sebuah inovasi yang mempunyai kontribusi sangat besar terhadap perubahan proses pembelajaran, dimana proses belajar tidak lagi hanya mendengarkan uraian materi dari guru tetapi siswa juga melakukan aktivitas lain seperti mengamati, melakukan, mendemonstrasikan, dan lain-lain. Materi bahan ajar dapat divisualisasikan dalam berbagai format dan bentuk yang lebih dinamis dan interaktif sehingga learner atau murid akan termotivasi untuk terlibat lebih jauh dalam proses pembelajaran tersebut.

Ada dua aspek yang paling menonjol dalam metodologi pembelajaran, yakni metode dan media pembelajaran sebagai alat bantu mengajar. Media pembelajaran dapat dikategorikan sebagai faktor eksternal yang ikut mempengaruhi proses pembelajaran di kelas, baik pada diri pengajar maupun pembelajar. Berdasarkan hasil penelitian menunjukkan bahwa pengetahuan seseorang diperoleh dari pengalaman pendengaran $11 \%$, dari pengalaman penglihatan $83 \% .^{4}$ Disisi lain, kemampuan daya ingat yaitu berupa pengalaman yang diperoleh dari apa yang didengar $20 \%$, dari pengalaman apa yang dilihat $50 \% .{ }^{5}$ Nilai dan kegunaan media pembelajaran dapat meningkatkan kualitas proses pembelajaran dan hasil belajar yang dicapai dalam proses pembelajaran. Penggunaan alat-alat bantu mengajar, peraga pendidikan dan media pembelajaran di sekolah-sekolah mulai menyesuaikan dengan perkembangan teknologi. Fokusnya adalah semua peralatan dan perlengkapan sekolah tersebut harus disesuaikan dengan tuntutan kurikulum dan materi, metode dan tingkat kemampuan siswa untuk mencapai tujuan

1 Sue Bennett and Karl Maton, "Beyond the 'Digital Natives' Debate: Towards a More Nuanced Understanding of Students' Technology Experiences," Journal of Computer Assisted Learning 26, no. 5 (2010): $321-31$.

${ }^{2}$ Ruth Xiaoqing Guo, Teresa Dobson, and Stephen Petrina, "Digital Natives, Digital Immigrants: An Analysis of Age and ICT Competency in Teacher Education," Journal of Educational Computing Research 38, no. 3 (2008): 235-54.

${ }^{3}$ Guo, Dobson, and Petrina.

${ }^{4}$ A Isa, "Keefektifan Pembelajaran Berbantuan Multimedia Menggunakan Metode Inkuiri Terbimbing Untuk Meningkatkan Minat Dan Pemahaman Siswa," Jurnal Pendidikan Fisika Indonesia 6, no. 1 (2010).

${ }^{5}$ Isa. 
pembelajaran. Perkembangan teknologi informasi telah mempengaruhi penggunaan berbagai jenis media sebagai alat bantu dalam proses pembelajaran. Maka dari itu, para pendidik diharapkan dapat menggunakan alat-alat atau perlengkapan tersebut secara efektif dan efesien dalam pembelajaran di kelas. ${ }^{6}$

Melalui observasi awal yang dilakukan oleh penulis terungkap bahwa di SMA Negeri 9 Bone mengalami permasalahan pada umumnya sama dengan permasalahan yang telah dipaparkan tentang rendahnya minat belajar. Pernyaataan ini diperkuat dengan nilai rata-rata hasil belajar siswa Kelas X IPA.3 SMA Negeri 9 Bone Kecamatan yang diperoleh pada Semester I Tahun Pembelajaran 2017/2018 yaitu $\leq 75$, yang merupakan standar ketuntasan belajar minimal siswa untuk mata pelajaran di SMA Negeri Bone. Ada beberapa cara yang dapat digunakan untuk meningkatkan minat belajar siswa, antara lain: 1) menggunakan metode mengajar yang bervariasi, 2) menumbuhkan lingkungan belajar yang kreatif dan kondusif, 3) menghubungkan pelajaran dengan pengalaman siswa, 4) memberi hadiah kepada siswa yang berprestasi dan sebaliknya, 5) menggunakan alat peraga, 6) belajar dan bermain, dan 7) menggunakan media pembelajaran dan lain-lain.

Kata atau istilah belajar bukanlah sesuatu yang baru, sudah sangat dikenal secara luas, namun dalam pembahasan belajar ini masing-masing ahli memiliki pemahaman dan definisi yang berbedabeda, walaupun secara praktis masing-masing kita sudah sangat memahami apa yang dimaksud belajar tersebut. Oleh karena itu untuk menghindari pemahaman yang beragam tersebut. Belajar dapat didefinisikan sebagai suatu proses dimana suatu organisme berubah perilakunya sebagai akibat pengalaman. ${ }^{7}$ Bagi Gagne, belajar dimaknai sebagai suatu proses untuk memperoleh motivasi dalam pengetahuan, keterampilan, kebiasaan, dan tingkah laku. ${ }^{8}$

Minat merupakan suatu kasukaan, kegemaran atau kesenangan akan sesuatu. ${ }^{9}$ Sadirman menambahkan bahwa minat merupakan suatu kondisi yang terjadi apabila seseorang melihat ciri-ciri atau arti sementara situasi yang dihubungkan dengan keinginan-keinginan atau kebutuhan-kebutuhan sendiri. ${ }^{10}$ Jika dikaitkan dengan proses pembelajaran, maka minat belajar menurut Olivia adalah sikap ketaatan pada kegiatan belajar, baik menyangkut perencanaan jadwal belajar maupun inisiatif melakukan usaha tersebut dengan sungguh-sungguh. ${ }^{11}$ Jadi, dapat ditarik benang merah bahwa minat belajar adalah keinginan untuk melakukan sesuatu karena ketertarikan dan kesenangan akan perkerjaan itu termasuk dalam hal belajar.

Terkait media pembelajaran, literatur sebelumnya banyak mendefinisikannya sebagai alat atau bentuk stimulasi yang berfungsi untuk menyampaikan pesan pembelajaran. Disisi lain, ada yang mendefinsikan "Media" sebagai bentuk jamak dari kata "medium", yang secara harfiah berarti "perantara atau pengantar. ${ }^{12}$ Kaitannya dengan ranah pendidikan, istilah media pendidikan dan media pembelajaran pada beberapa literatur menunjukkan makna yang sama sehingga digunakan secara bergantian. ${ }^{13}$ Gagne mendifinisikan media pembelajaran adalah berbagai jenis komponen dalam linkungan peserta didik yang dapat menumbuhkan sikap belajar. ${ }^{14}$ Menurut Donald P. Ely \& Vernon S. Gerlach dalam pengertian media ada dua bagian, yaitu arti sempit dan arti luas. Arti sempit, bahwa media itu berwujud: grafik, foto, alat, mekanik dan elektronik yang di gunakan untuk menangkap

\footnotetext{
${ }^{6}$ Hujair A H Sanaky, Media Pembelajaran Interaktif-Inovatif (Yogyakarta: Kaukaba Dipantara, 2013).

${ }^{7}$ Ahmad Susanto, Teori Belajar dan Pembelajaran di Sekolah Dasar (Kencana, 2016).

${ }^{8}$ Susanto.

${ }^{9}$ Try Junita Wulandari, Sahat Siagian, and Abdul Muin Sibuea, "Pengembangan Media Pembelajaran dengan Alikasi Macromedia Flash Pada Mata Pelajaran Matematika," Jurnal Teknologi Informasi \& Komunikasi Dalam Pendidikan 5, no. 2 (2019).

${ }^{10}$ Susanto, Teori Belajar dan Pembelajaran di Sekolah Dasar.

${ }^{11}$ Siti Nurhasanah and A Sobandi, "Minat Belajar Sebagai Determinan Hasil Belajar Siswa," Jurnal Pendidikan Manajemen Perkantoran 1, no. 1 (2016): 135-42.

12 Ali Mudlofir and Evi Fatimatur Rusydiyah, Desain Pembelajaran Inovatif, Jakarta: Raja Grafindo

13 Mawar Ramadhani, "Efektivitas Penggunaan Media Pembelajaran E-Learning Berbasis Web Pada Pelajaran Teknologi Informasi Dan Komunikasi Terhadap Hasil Belajar Siswa Kelas X SMA Negeri 1 Kalasan," Skripsi (Universitas Negeri Yogyakarta, 2012).

${ }^{14}$ Mudlofir and Rusydiyah, Desain Pembelajaran Inovatif.
} Persada, 2016. 
memproses serta menyampaikan informasi. ${ }^{15} \mathrm{Jadi}$, dapat disimpulkan bahwa media pembelajaran merupakan kegiatan yang dapat menciptakan suatu kondisi sehingga memungkinkan peserta didik dapat memperoleh pengetahuan, keterampilan dan sikap yang baru.

Perkembangan teknologi informasi telah membawa pengaruh yang besar terhadap dunia pendidikan. Berbagai inovasi selalu diusahakan oleh para pelaku pendidikan, misalnya terkait materi pendidikan, kebutuhan kepala sekolah, dan kebutuhan guru saat mengajar. Hal ini yang kemudian menuntut semua pihak, baik itu guru maupun kepala sekolah harus dapat menyesuaikan diri dengan perkembangan teknologi informasi tersebut. Salah satu bentuk inovasi yang muncul adalah media pembelajaran berbasis teknologi informasi.

Media pembelajaran berbasis teknologi informasi secara konseptual adalah pembelajaran tatap muka dengan dukungan teknologi informasi. Namun di lain pihak, jika kepuasan itu berkurang maka minat seseorang pun akan berkurang. Minat yang dibicarakan disini berbeda dengan minat yang sifatnya sesaat yang biasa dikenal dengan keinginan sesaat. Perbedaanya adalah minat sesungguhnya lebih menetap atau bertahan lama diri seseorang. Meskipun keinginan sesaat ini pada awalnya dapat menjadi motivasi seperti halnya minat, tetapi lama-kelamaan dapat berkurang karena aktivitas yang membangkitkannya hanya bersifat sementara atau sesaat. Lebih dari itu minat dapat berperan secara efektif untuk menunjang pengambilan keputusan oleh seseorang atau insititusi.

Berdasarkan literatur dan hasil penenlitian sebelumnya, teknologi informasi yang diintegrasikan dalam media pembelajaran yang tidak hanya berupa tulisan-tulisan yang membosankan tetapi juga dapat menampilkan gambar-gambar dan suara yang menarik minat siswa dalam belajar. Selain itu, penelitian terkait media pembelajaran yang berbasis teknologi informasi belum banyak dilakukan di Kabupaten Bone, Provinsi Sulawesi Selatan, Indonesia. Hal ini yang kemudian menarik untuk diteliti dengan harapan penggunaan media pembelajaran berbasis teknologi informasi pada siswa kelas X IPA.3 Negeri 9 Bone maka minat belajar siswa akan mengalami peningkatan.

\section{METODE}

Penelitian ini tergolong dalam penelitian tindakan kelas (classroom action research) yang dirancang untuk guru dan peneliti agar mampu memecahkan masalah-masalah yang terjadi di kelas, dengan adanya partisipasi dan kolaborasi antara peneliti dengan anggota kelompok sasaran, dalam hal ini guru. Penetian tindakan kelas adalah suatu pencermatan terhadap kegiatan belajar berupa tindakan yang sengaja dimunculkan dan terjadi dalam kelas.

Pengambilan sampel penelitian ini menggunakan teknik random sampling, dimana sampel yang terpilih adalah siswa kelas X IPA.3 SMA Negeri 9 Bone. Sampel dalam penelitian ini berjumlah 26 orang yang terdiri atas perempuan 14 orang dan laki-laki 12 orang.

Pelaksanaan penelitian ini direncanakan dua siklus yakni siklus I dan siklus II. Siklus I akan dilaksanakan lima kali pertemuan dan siklus II direncanakan empat kali pertemuan. Setiap siklus dilaksanakan sesuai dengan kompetensi yang ingin dicapai dan faktor- faktor yang diselidiki. Prosedur penelitian tindakan kelas untuk setiap siklus meliputi: 1) perencanaan, 2) pelaksanaan tindakan,3) obsevasi dan evaluasi, dan 4) refleksi dalam setiap siklus yang disajikan pada Gambar $1 .{ }^{16}$

${ }^{15}$ Mudlofir and Rusydiyah.

${ }^{16}$ Arikunto Suharsimi and Supardi Suhardjono, Penelitian Tindakan Kelas (Jakarta: Bumi Aksara, 2006). 


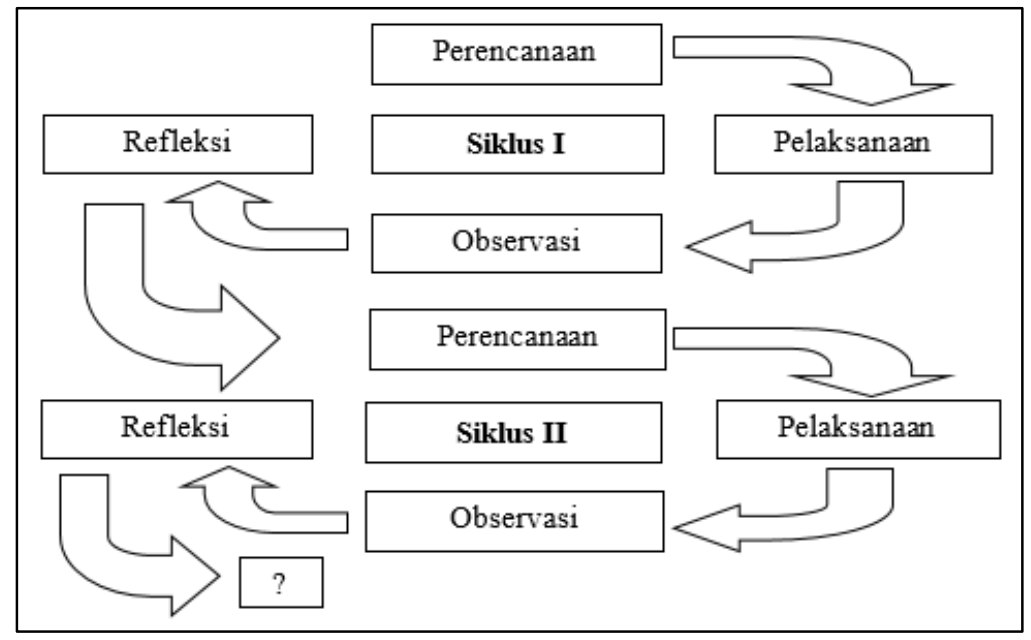

Gambar 1. Prosedur Penelitian Tindakan Kelas

Data dalam penelitian ini diperoleh dari hasil observasi, angket, dan tes. Data observasi berupa hasil pengamatan peneliti terhadap minat siswa dalam pembelajaran. Data hasil angket berupa minat siswa dalam melakukan kegiatan dan dapat membangkitkan gairah seseorang untuk memenuhi kesediaanya dalam belajar. Data hasil tes berupa jawaban tertulis dari siswa yang disusun untuk mengukur kualitas, abilitas, keterampilan atau pengetahuan dari seseorang atau sekelompok individu.

Adapun teknik pengumpulan data yang digunakan dalam penelitian ini adalah sebagai berikut (1) data tentang minat belajar diambil dari lembar angket yang diberikan sebelum pelaksanaan tindakan, setelah pelaksanaan tindakan siklus I dan setelah pelaksanaan tindakan siklus II; (2) data mengenai aktivitas siswa dalam mengikuti proses belajar mengajar diperoleh melalui lembar observasi selama proses pembelajaran; (3) data mengenai peningkatan hasil belajar diperoleh dari tes hasil belajar yang dilaksanakan diakhir siklus; dan (4) untuk menghitung minat belajar siswa digunakan tekhnik analisis deskriptif kuantitatif. Teknik analisis statistic deskriptif yang digunakan adalah dengan menghitung skor rata-rata, skor tertinggi, skor terendah pada instrument penelitian yang tak lain adalah angket respond an lembar aktivitas siswa itu sendiri.

Data tentang angket respon siswa yang diperoleh dari lembar angket yang dibagikan setelah akhir siklus kemudian dihitung untuk memperoleh indeks minat siswa dalam pembelajaran. Adapun rumus yang digunakan untuk menghitung indeks minat belajar siswa adalah sebagai berikut.

Keterangan:

$$
\operatorname{Pr}=\frac{\sum R s}{\sum N} \times 100 \%
$$

Pr: Persentase yang memberikan respon terhadap kategori tertentu yang ditanyakan dalam angket.

$\sum R s$ : Banyaknya siswa yang memberikan respon terhadap kategori tertentu yang ditanyakan dalam angket

$\sum N:$ Jumlah siswa

Sementara itu, data tentang aktivitas siswa dan guru yang diperoleh melalui lembar observasi selama mengikuti proses pembelajaran dihitung dengan rumus sebagai berikut.

$$
\text { Po }=\frac{\text { Jumlah Skor Hasil Pengamatan }}{\text { Jumlah Siswa }} \times 100
$$

Untuk data hasil belajar, data dianalisis secara kuantitatif dengan menggunakan statistik deskriftif yaitu skor rata-rata dan presentase, nilai terendah dan nilai tertinggi yang dicapai siswa setiap siklus 
dengan bantuan SPSS. Data hasil belajar yang diperoleh dikategorikan berdasarkan kategorisasi standar yang ditetapkan oleh Departemen Pendidikan Nasional pada Tabel $1 .{ }^{17}$

Tabel 1. Teknik kategorisasi standar berdasarkan ketetapan Departemen Pendidikan Naasional

\begin{tabular}{cc}
\hline Nilai & Kategori \\
\hline $0-34$ & Sangat Rendah \\
$35-45$ & Redah \\
$55-65$ & Sedang \\
$65-84$ & Tinggi \\
$85-100$ & Sangat tinggi \\
\hline
\end{tabular}

\section{HASIL DAN PEMBAHASAN}

\section{Hasil}

Data hasil penelitian adalah data yang diperoleh dari tes hasil belajar siswa setelah pelaksanaan tindakan siklus I dan siklus II, hasil observasi selama pelaksanaan tindakan dan respon siswa terhadap model pembelajaran yang digunakan. Adapun hasil yang diperoleh dari dua siklus pelaksanaan penelitian ini dapat diuraikan sebagai berikut.

\section{Refleksi Siklus I}

Refleksi merupakan langkah yang dilakukan setelah mengetahui hasil dan tindakan pada siklus I. Berdasarkan hasil dari minat belajar tersebut, maka peneliti dan guru berdiskusi untuk melakukan tindakan selanjutnya dalam rangka memperbaiki siklus I karena pada siklus I pelaksanaan pembelajaran dengan menggunakan melalui media pembelajaran berbasis teknologi informasi belum berjalan dengan optimal. Ada dua faktor yang menyebabkan pelaksanaan pembelajaran dengan menggunakan melalui media pembelajaran berbasis teknologi informasi belum berjalan dengan optimal, yakni Media pembelajaran yang digunakan ini membuat siswa merasa baru dan model pembelajaran yang digunakan masih membingungkan banyak siswa.

Pada siklus I ini proses belajar mengajar diawali dengan memperkenalkan media pembelajaran yang akan digunakan dalam proses pembelajaran yaitu melalui media pembelajaran berbasis teknologi informasi. Media pembelajaran yang digunakan ini membuat siswa merasa baru dengan hal tersebut karena selama ini pembelajaran yang digunakan adalah model pembelajaran langsung sehingga respon dan minat siswa terhadap pembelajaran ini masih kurang. Banyak siswa yang terlihat bingung dengan model pembelajaran yang digunakan, kebingungan siswa terlihat dari aktivitas siswa saat proses pembelajaran berlangsung dimana masih ada siswa yang kurang memperhatikan penjelasan guru.

Selain itu, keaktifan dan minat belajar matematika siswa dalam bertanya masih belum optimal karena siswa belum terbiasa dengan proses pembelajaran yang berupaya untuk mengajukan pertanyaan. Siswa masih mempunyai rasa enggan dan malu untuk bertanya. Selain itu, siswa juga belum optimal dalam kegiatan diskusi kelompok seperti kurang berminat untuk belajar dan masih ada siswa yang tidak aktif karena kurang memahami pentingnya kerjasama dalam mencari informasi untuk pemecahan masalah, memecahkan masalah dalam diskusi, melaksanakan diskusi kelompok sesuai petunjuk guru dikarenakan siswa mengobrol dengan temannya bukan mengenai materi yang belum dipahami.

Berdasarkan pengamatan dari minat belajar siswa dan hasil tersebut, ada beberapa hal yang perlu ditekankan yaitu guru dapat mengatur waktu ketika proses pembelajaran berlangsung sehingga pelaksanaan pembelajaran dapat optimal dan guru memberikan arahan kepada siswa untuk lebih aktif dan berminat untuk belajar matematika ketika kegiatan belajar mengajar berlangsung yaitu dengan mengajukan pertanyaan, berdiskusi dan memperhatikan penjelasan guru.

Oleh karena itu, peneliti dan guru sepakat untuk melanjutkan siklus II. Dalam siklus II merencanakan perbaikan dengan cara guru memberi arahan kepada siswa untuk lebih aktif dan memiliki minat dalam pembelajaran yaitu apabila masih banyak siswa yang belum bertanya maka guru akan mendatangi siswa untuk bertanya. Agar siswa aktif berdiskusi maka siswa diberi waktu yang lebih untuk

${ }^{17}$ Kartianom Kartianom and Djemari Mardapi, "The Utilization of Junior High School Mathematics National Examination Data: Conceptual Error Diagnosis," REiD (Research and Evaluation in Education) 3, no. 2 (2018). 
berdiskusi dan semua anggota kelompok ikut terlibat dalam mencari informasi sehingga siswa dapat mencari informasi dalam pemecahan masalah, siswa melaksanakan diskusi kelompok sesuai petunjuk guru. Selain itu, agar siswa fokus ketika guru menjelaskan, siswa diperintahkan untuk menulis dan menambahkan materi yang tidak ada di buku, hal ini diharapkan dapat mengoptimalkan partisipasi minat siswa yang belum tergali sehingga membantu pencapaian keaktifan belajar siswa yang optimal.

\section{Refleksi Siklus II}

Berdasarkan hasil pengamatan siklus II menunjukkan adanya peningkatan skor indikator dari siklus sebelumnya. Rencana perbaikan yang direncanakan pada siklus I dapat dilaksanakan dengan baik pada siklus II. Hal ini terlihat dari data observasi siswa pada Tabel 2 yang telah mencapai kriteria minimal yang telah ditentukan yaitu sebesar $80 \%$.

Tabel 2. Peningkatan Hasil Belajar Siswa Kelas X IPA 3 SMA Negeri 9 Bone Pada Siklus I Dan II

\begin{tabular}{cccccc}
\hline \multirow{2}{*}{ Skor } & \multirow{2}{*}{ Kategori } & \multicolumn{2}{c}{ Frekuensi } & \multicolumn{2}{c}{ Presentase (\%) } \\
\cline { 3 - 6 } & & Siklus I & Siklus II & Siklus I & Siklus II \\
\hline $0-34$ & Sangat rendah & 0 & 0 & 0.00 & 0.00 \\
$35-54$ & Rendah & 6 & 0 & 23,08 & 0,00 \\
$55-64$ & Sedang & 3 & 1 & 11,54 & 3,84 \\
$65-84$ & Tinggi & 15 & 10 & 57,69 & 38,47 \\
$85-100$ & Sangat tinggi & 2 & 15 & 6,67 & 57,6 \\
\hline Jumlah & & 26 & 26 & 100,00 & 100,00 \\
\hline
\end{tabular}

\section{Pembahasan}

Media pembelajaran yang digunakan dalam penelitian ini adalah media pembelajaran berbasis teknologi informasi. Tindakan yang dilakukan dengan tipe tersebut dapat meningkatkan minat belajar siswa dalam pembelajaran. Proses belajar mengajar diawali dengan membagi siswa menjadi beberapa kelompok berdasarkan yang diterapakan melalui media pembelajaran berbasis teknologi informasi yaitu terdiri atas 5 kelompok yang berisi 5-6 orang setiap kelompok, pembagian kelompok ini dipilih yang memiliki kemampuan, jenis kelamin dan ras yang berbeda. Guru membagikan materi, dan siswa belajar dalam kelompok mereka masing-masing. Pada saat siswa membaca materi yang diberikan dalam kelompok guru memberikan arahan kepada setiap kelompok untuk memberikan tanda pada bacaan yang tidak dimengerti dengan berupa pertanyaan. Apabila ada dari anggota kelompok yang tidak mengerti dengan tugas yang diberikan maka anggota kelompok yang lain bertanggung jawab untuk menjelaskanya, sebelum mengajukan pertanyaan tersebut kepada guru. Kemudian siswa diberikan soal latihan yang melatih, mengembangkan dan meningkatkan kemampuan siswa agar lebih meningkatkan pemahaman terhadap materi yang telah diberikan. Dalam penelitian ini, data yang diperoleh berupa data kuantitatif dan data kualitatif, data kualitatif berupa lembar observasi dan angket respon siswa sedangkan data kuantitatif berupa tes hasil belajar yang dilaksanakan setiap akhir siklus.

Berdasarkan hasil penelitian, analisis data, dan pembahasan, maka dapat disimpulkan bahwa dengan menggunakan media pembelajaran berbasis teknologi informasi dapat meningkatkan minat belajar siswa kelas X IPA 3 SMA Negeri 9 Bone. Hal ini dapat dilihat dari hasil penelitian yang dilaksanakan selama 2 siklus, yakni Minat belajar dan hasil belajar pada siklus I terdapat 9 orang dengan presentase 34,61\% termasuk dalam kategori belum tuntas dan 17 Orang dengan presentase 65,39\% yang termasuk dalam kategori tuntas, berarti ada 9 orang yang perlu melakukan perbaikan karena belum mencapai kriteria ketuntasan. Hal ini menunjukan bahwa pada siklus I ketuntasan secara klasikal belum mencapai $80 \%$ maka perlu dilanjutkan pada siklus II. Pada siklus II terdapat 1 orang dengan presentase $3,84 \%$ termasuk dalam kategori belum tuntas dan 25 Orang dengan presentase 96,16\% yang termasuk dalam kategori tuntas. Hal ini menunjukan bahwa pada siklus II ketuntasan secara klasikal sudah mencapai lebih dari $80 \%$. Hasil penelitian ini juga mendukung hasil penelitian Hollman yang mengatakan bahwa penggunaan media pembelajaran berbasis teknologi dapat meningkatkan minat belajar siswa. ${ }^{18}$ Ray, Bala, \& Dasgupta juga menemukan hasil yang sama bahwa model pembelajaran

18 Angela Hollman et al., "Information Technology Pathways in Education: Interventions with Middle School Students," Computers \& Education, 2019. 
yang melibatkan teknologi sebagai media pembelajaran dapat membantu meningkat minat dan prestasi belajar siswa. ${ }^{19}$

Berdasarkan hasil penelitian dan pembahasan di atas menunjukkan bahwa melalui media pembelajarn pembelajaran berbasis teknologi informasi dapat meningkatkan minat belajar siswa kelas X IPA 3 SMA Negeri 9 Bone. Untuk guru mata pelajaran, dan seluruh guru SMA Negeri 9 Bone pada umumnya, penyusun menyarankan dalam pembelajaran pertemuan-pertemuan selanjutnya menggunakan media pembelajaran teknologi informasi agar minat belajar lebih meningkatkan prestasi belajar yang sesuai harapan. Untuk Kepala SMA Negeri 9 Bone, media pembelajaran berbasis teknologi informasi ini dapat dijadikan sebagai alternatif dalam proses belajar mengajar tidak hanya kelas $\mathrm{X}$ namun keseluruhan kelas X, XI dan XII sekaligus mewujudkan cita-cita menjadi sekolah berbasis teknologi. Dan satu lagi untuk SMA Negeri 3 Bone, harapan terwujudnya sekolah berbasis teknologi harus dibarengi pula oleh peningkatan fasilitas media pembelajaran. Hal ini sejalan dengan temuan Kartianom \& Retnawati yang mengatakan bahwa satu diantara banyak faktor yang mempengaruhi prestasi belajar siswa adalah fasilitas media pembelajaran. ${ }^{20}$ Jika sekarang telah terwujud tiap guru diwajibkan memiliki laptop, hendaknya tiap kelas juga dilengkapi LCD proyektor. Dari keseluruhan pembelajaran yang telah diterapkan pada siklus I dan siklus II masih perlu banyak pengembangan, karena teknologi informasi tidak cukup sampai disitu saja. Masih banyak pengembangan yang lebih inovatif dan kreatif, dari sini guru dituntut untuk lebih aktif dalam mengikuti berbagai pelatihan teknologi pendidikan, agar bisa lebih maksimal dalam penerapan media pembelajaran berbasis teknologi informasi.

\section{SIMPULAN DAN SARAN}

\section{Simpulan}

Berdasarkan hasil dan pemabahasan dapat disimpulkan bahwa: (1) pembelajaran dengan menggunakan media berbasis teknologi informasi dapat meningkatkan minat belajar siswa kelas $\mathrm{X}$ IPA.3 SMA Negeri 9 Bone; (2) Aktifitas siswa dalam proses pembelajaran juga mengalami peningkatan, meskipun berdasarkan lembar aktivitas siswa pada siklus I masih dirasakan beberapa kendala namun pada siklus II menunjukan adanya peningkatan secara signifikan; dan (3) rata-rata hasil belajar siswa kelas X IPA.3SMA Negeri 9 Watampone juga mengalami peningkatan dimana pada siklus I sebesar 67,34\% dan pada siklus II rata-rata hasil belajar siswa meningkat menjadi 83,19\%.

\section{Saran}

Secara keseluruhan, pembelajaran yang telah diterapkan pada siklus I dan siklus II sudah baik, hanya sajamasih perlu banyak pengembangan, karena teknologi informasi tidak cukup sampai disitu saja. Masih banyak pengembangan yang lebih inovatif dan kreatif. Untuk guru, dituntut untuk lebih aktif dalam mengikuti berbagai pelatihan teknologi pendidikan, agar bisa lebih maksimal dalam penerapan media pembelajaran berbasis teknologi informasi.

\section{DAFTAR PUSTAKA}

Bennett, Sue, and Karl Maton. "Beyond the 'Digital Natives' Debate: Towards a More Nuanced Understanding of Students' Technology Experiences.” Journal of Computer Assisted Learning 26, no. 5 (2010): 321-31.

Guo, Ruth Xiaoqing, Teresa Dobson, and Stephen Petrina. "Digital Natives, Digital Immigrants: An Analysis of Age and ICT Competency in Teacher Education." Journal of Educational Computing Research 38, no. 3 (2008): 235-54.

Hollman, Angela, Travis J Hollman, Frank Shimerdla, Matthew R Bice, and Megan Adkins. "Information Technology Pathways in Education: Interventions with Middle School Students." Computers \& Education, 2019.

${ }^{19}$ Arghya Ray, Pradip Kumar Bala, and Shilpee A Dasgupta, "Role of Authenticity and Perceived Benefits of Online Courses on Technology Based Career Choice in India: A Modified Technology Adoption Model Based on Career Theory," International Journal of Information Management 47 (2019): 140-51.

${ }^{20} \mathrm{~K}$ Kartianom and Heri Retnawati, "Why Are Their Mathematical Learning Achievements Differents? Re- Analysis TIMSS 2015 Data In Indonesia, Japan, and Turkey," International Journal on New Trends in Education and Their Implications 9, no. 2 (2018): 33-46. 
Isa, A. "Keefektifan Pembelajaran Berbantuan Multimedia Menggunakan Metode Inkuiri Terbimbing Untuk Meningkatkan Minat Dan Pemahaman Siswa." Jurnal Pendidikan Fisika Indonesia 6, no. 1 (2010).

Kartianom, K, and Heri Retnawati. "Why Are Their Mathematical Learning Achievements Differents? Re- Analysis TIMSS 2015 Data In Indonesia, Japan, and Turkey." International Journal on New Trends in Education and Their Implications 9, no. 2 (2018): 33-46.

Kartianom, Kartianom, and Djemari Mardapi. "The Utilization of Junior High School Mathematics National Examination Data: Conceptual Error Diagnosis." REiD (Research and Evaluation in Education) 3, no. 2 (2018).

Mudlofir, Ali, and Evi Fatimatur Rusydiyah. Desain Pembelajaran Inovatif. Jakarta: Raja Grafindo Persada, 2016.

Nurhasanah, Siti, and A Sobandi. "Minat Belajar Sebagai Determinan Hasil Belajar Siswa." Jurnal Pendidikan Manajemen Perkantoran 1, no. 1 (2016): 135-42.

Ramadhani, Mawar. "Efektivitas Penggunaan Media Pembelajaran E-Learning Berbasis Web Pada Pelajaran Teknologi Informasi Dan Komunikasi Terhadap Hasil Belajar Siswa Kelas X SMA Negeri 1 Kalasan.” Skripsi. Universitas Negeri Yogyakarta, 2012.

Ray, Arghya, Pradip Kumar Bala, and Shilpee A Dasgupta. "Role of Authenticity and Perceived Benefits of Online Courses on Technology Based Career Choice in India: A Modified Technology Adoption Model Based on Career Theory." International Journal of Information Management 47 (2019): 140-51.

Sanaky, Hujair A H. Media Pembelajaran Interaktif-Inovatif. Yogyakarta: Kaukaba Dipantara, 2013. Suharsimi, Arikunto, and Supardi Suhardjono. Penelitian Tindakan Kelas. Jakarta: Bumi Aksara, 2006. Susanto, Ahmad. Teori Belajar Dan Pembelajaran Di Sekolah Dasar. Kencana, 2016.

Wulandari, Try Junita, Sahat Siagian, and Abdul Muin Sibuea. "Pengembangan Media Pembelajaran Dengan Alikasi Macromedia Flash Pada Mata Pelajaran Matematika." Jurnal Teknologi Informasi \& Komunikasi Dalam Pendidikan 5, no. 2 (2019). 